\title{
Evaluating Influence of Manpower Plan Implementation on Staff Retention in Senior Secondary Schools in Adamawa State, Nigeria
}

\author{
Huraira Muhammad Furo \\ Department of Physical Science Education, School of Technology and Science Education, Modibbo Adama University of \\ Technology, Yola, Nigeria \\ hurairamuhammadfuro@gmail.com \\ Martins Fabunmi \\ Department of Physical Science Education, School of Technology and Science Education, Modibbo Adama University of \\ Technology, Yola, Nigeria
}

DOI: 10.47299/bsjmm.v2i1.64

\begin{abstract}
The paper evaluated the influence of the effects of manpower planning on staff retention in senior secondary schools in Adamawa State, Nigeria. The study had five objectives. The population of the study was 5,968 which consists of 326 principals and 5,642 teachers of public Senior Secondary schools of the five education zones in Adamawa State. The study sampled 900 teachers and staff using the multistage sampling technique. Data were generated by the administration of a structured questionnaire to respondents. Mean and the standard deviation was the statistical tool used to achieve the objectives. The findings of the study revealed that there was moderately high level of effectiveness of manpower plan implementation on staff retention in Senior Secondary Schools in Adamawa State. There was a very high level of effectiveness of manpower plan evaluation on staff retention in Senior Secondary Schools in Adamawa State. The study recommended among others that: the government should come out with a comprehensive, clearly articulated, and documented Manpower Training and Development Policy, and concentration should be on staff development. All staff should be given a copy of this Training and Development Policy document.
\end{abstract}

Keywords: manpower, plan implementation, staff retention, influence, evaluating

\section{Introduction}

Manpower is the basis of all resources and it is the indispensable means of converting other resources to man kind's use and benefits (Chukwuka, 2016). Manpower planning and development as a function of management is highly indispensable in the achievement of organizational objectives. There is need to plan for the various resources such as human, material and time, etc., in order to achieve stated objectives. Manpower planning which is synonymous to human resource development approach is critical to achieving the overall goals of any educational enterprise globally (Okoye \& Ezeijiofor, 2013). Manpower planning can be conceptualized as a managerial function of harnessing and integrating the social system for efficient service delivery through combining man and materials (Chukwuka, 2016). The ability to plan manpower in any organisation can be in-born and acquired skills of the manager. Ofoegbu \& Ofoegbu (2017)) argued that the discourse of man power planning or rather human resource development cannot be completed without the mentioning of the relevant educational practices that personnel were exposed to, which precipitated into experiences and competencies to 
handle critical organisational decisions and obligations. There seems to be a growing concern over the effectiveness of manpower planning and its influence on the successful operations of organizations.

The successes or failures of an organisation are hinged on the quantity and quality of the personnel hired to execute assorted functions within organization (Torlak et al., 2021). New paradigm organizations recognize that an important element in business management planning is the need to successfully motivate and retain especially high talent employees who survive organisational restructuring, downsizing, consolidation, reorganizing or re-engineering initiatives (Budur and Poturak, 2020; Asfaw, Argam, \& Bauossa, 2015; Poturak et al., 2020). Though an organization has a good strategy and sustainable funds, it will not reach success without loyal and well-trained human resources (Demir et al., 2020; Mohammed et al., 2020). This has led organizations to put in more effort to ensure that there are right people, in the right place, at the right time (Zaim et al., 2020). According to Peter (2014), society has now become knowledge-based where clearly human capital is considered a key resource and indispensable to the survival of any organization. Increasingly, organizations are competing for the best talent employees. Failing to properly plan for their human resources, employers are forced to become reactive, rather than proactive (Chukwuka, 2016).

Staff retention refers to the ability of an organization to retain its staff (Scribd, 2013). Staff retention can be represented by a simple statistic (for example, a retention rate of $80 \%$ usually indicates that an organization kept $80 \%$ of its staff in a given period). However, many consider staff retention as relating to the efforts by which employers attempt to retain the staff in their workforce. In this sense, retention becomes the strategies rather than the outcome (Wisker \& Kwiatek, 2019). Adherence to activities such as equal employment opportunity, implementation of affirmative action policies, expanding employee benefit systems and promoting creativity in job designs and processes can lead to retention of good employees (Nassari, 2013).

Acquiring a right person is a challenging task, but retaining the person in the organization is a more challenging one (Ezeani \& Oladele, 2013). Any organization prefers to possess the right mix of people in the organization to perform the organizational tasks and improve the productivity and profitability (Budur and Demir, 2019; Okoye \& Ezejiofor, 2013). Scribd (2013) opined that the ability of effective human resource management to attract, retain, and motivate employees has been a demanding task both for educational manager in schools. In view of this fact, for the better utilization of human resource in the schools, mainly in planning, recruitment and selection, training and academic staff performance, teachers' salaries, working conditions, and on-the-job training require great concern of the higher body of educational officers and the policy makers (Chukwuka, 2016; Mohammed et al., 2020).

It has been observed recently with a greater concern, the rate at which teachers, especially the trained teachers at various levels of education are exiting the teaching job. Teachers, being the key players in knowledge transmission process, seem to be not satisfied with their condition of service. It appears people only opt for the teaching job when a better option is not available. Immediately when a greener pasture is spotted, these teachers seem to not hesitate to abandon their teaching to grab a perceived better employment. This ugly trend has been in persistent for many years and the education sector seems to be worst hit by it. There is fear looming in the sky that if this scenario is allowed to go on unchecked, definitely the yearning of Nigeria to be among the most developed economy of the world would be a mirage. There are many speculations as to what precipitated this problem among which is the manpower planning approach of the relevant stake-holders. In this regard, this study attempt to 
evaluate the influence of manpower plan implementation on staff retention in senior secondary schools in Adamawa State, Nigeria.

\section{Methodology}

\section{Research Design}

The correlational survey research design was adopted for the study. The correlation research approach involves the study of relationships between two variables as intended by the research to analyze manpower planning effectiveness (independent variable) and staff retention (Dependent variable) in Senior Secondary Schools in Adamawa State Nigeria.

\section{The Study Area and Sampling Method}

The study was carried out in Adamawa State, which is in North-East Geo-Political Zone, Nigeria, with its capital at Yola. The State had five education zones namely: Gombi, Mubi, Yola, Numan and Ganye Zones with a total of 305 Senior Secondary Schools, 326 principals and 5,642 teachers, respectively, of public Senior Secondary Schools. The study sample had a total of 600 subjects including both principals and the teachers. The sample size was estimated using Taro Yamane's formula. The study sample was drawn from three Education Zones. The multistage sampling technique at four levels was employed in selecting participants for the study. In the first stage of the sampling procedure, a stratified random sampling technique was adopted based on the five educational zones in Adamawa State. At this stage, units (zones) were selected using the probability equal to one strategy. This implies that three educational zones in Adamawa State were selected. At the second stage, stratified random sampling technique was used in selecting participating Local Government Areas (LGAs) in the study. At the third stage, two LGAs were selected from each of the three educational zones in the State to make up 6 LGAs using simple random sampling technique (balloting with replacement). At final stage in all the local governments selected, the public senior secondary schools were used for the study. Purposive sampling was used to select 20 principals out of the sample of 326 principals. Also, 580 teachers were sampled out of 5,642 teachers. In all, 600 respondents were totally sampled. The criteria for selected the principals is based on their educational qualification either B-Tech: or B-Ed, while teachers was based on their minimum qualification to teach, that is, Nigeria Certificate in Education (NCE) and alike.

\section{Research Instrument and Data Collection}

The instrument used for data collection was a structured questionnaire which made up of open-ended and closed-ended items which were self-constructed. The questionnaire was tagged: Manpower Planning Effectiveness and Staff Retention Questionnaire (MPESRQ). The questionnaire were subdivided into two i.e. section $A$ and $B$; Section $A$ sought to elicit information of the respondents on personal data, while Section B sought the opinion of respondents on the following variables; Current Manpower needs Assessment, Manpower need Projection, Manpower Plan Implementation, Manpower Plan Evaluation and Staff Retention. The instrument was validated by experts in the Department of Physical Sciences Education, Modibbo Adama University of Technology, Yola to check for the authenticity. After slight modifications, the instrument was approved for the study. Data were collected by administering the structured questionnaires to the respondents with the help of four trained research assistants. The respondents filled and returned the questionnaire on the spot in order to avoid missing of questionnaires. 


\section{Analysis of Data}

Descriptive statistics and Likert Scale on five-point scale were used for the data analysis. Specifically, mean and standard deviation were used to achieve the objectives. These were later presented in tables below.

\section{Results and Discussion}

\section{Level of Effectiveness of Manpower Plan Implementation in Senior Secondary schools in Adamawa State}

Table 1 indicates the mean and standard deviation of the level of effectiveness of manpower plan implementation in Senior Secondary Schools in Adamawa State. It was shown that a calculated mean score of 4.12 with a standard deviation of 1.352 was obtained for item 1, which states that our teachers always prepare lesson plan for every lesson delivery. The decision for item 1 was considered very high. A mean score of 3.96 with a standard deviation of 1.405 was obtained for item 2, which states that most of our teachers carried students along in introduction state of their lessons. The decision for item 2 is regarded as moderately high. A mean score of 4.25 with a standard deviation of 1.354 was obtained for item 3 , which states that most of our teacher present their lessons sequentially through steps. The decision for item 3 is regarded as very high. A mean score of 3.88 with a standard deviation of 1.445 was obtained for item 4 , which states that our teachers make use of appropriate instructional materials for every lesson delivered. The decision for item 4 is regarded as moderately high. A mean score of 3.72 with a standard deviation of 1.414 was achieved for item 5 , which states that the evaluation strategies employed by teachers in our school assist effective curriculum implementation. The decision for item 5 is regarded as moderately high. 
Table 1 Mean and Standard Deviation of the level of effectiveness of manpower plan implementation in Senior Secondary Schools in Adamawa State

\begin{tabular}{|c|c|c|c|c|}
\hline$S / N$ & Item & Mean & $\begin{array}{l}\text { Std. } \\
\text { Dev. }\end{array}$ & Decision \\
\hline 1. & $\begin{array}{l}\text { Our teachers always prepare lesson plan for every } \\
\text { lesson delivery. }\end{array}$ & 4.12 & 1.352 & Very High \\
\hline 2. & $\begin{array}{l}\text { Most of our teachers carried students along in } \\
\text { introduction stage of their lesson. }\end{array}$ & 3.96 & 1.405 & $\begin{array}{l}\text { Moderately } \\
\text { High }\end{array}$ \\
\hline 3. & $\begin{array}{l}\text { Most of our teachers present their lessons sequentially } \\
\text { through steps. }\end{array}$ & 4.25 & 1.354 & Very High \\
\hline 4. & $\begin{array}{l}\text { Our teachers make use of appropriate instructional } \\
\text { materials for every lesson delivered. }\end{array}$ & 3.88 & 1.445 & $\begin{array}{l}\text { Moderately } \\
\text { High }\end{array}$ \\
\hline 5. & $\begin{array}{l}\text { The evaluation strategies employed by teachers in our } \\
\text { school assist effective curriculum implementation. }\end{array}$ & 3.72 & 1.414 & $\begin{array}{l}\text { Moderately } \\
\text { High }\end{array}$ \\
\hline 6. & $\begin{array}{l}\text { The method of instructions used by our teachers } \\
\text { facilitates effective implementation of curriculum. }\end{array}$ & 3.86 & 1.456 & $\begin{array}{l}\text { Moderately } \\
\text { High }\end{array}$ \\
\hline 7. & $\begin{array}{l}\text { Most of our teachers don't have effective classroom } \\
\text { management. }\end{array}$ & 4.22 & 1.337 & Very High \\
\hline 8. & $\begin{array}{l}\text { Most of teachers don't have good communication } \\
\text { skills. }\end{array}$ & 3.65 & 1.503 & $\begin{array}{l}\text { Moderately } \\
\text { High }\end{array}$ \\
\hline 9. & Teachers in my school mastered subjects they thought. & 4.12 & 1.364 & Very High \\
\hline 10. & $\begin{array}{l}\text { Assignments and test are frequently given by teachers } \\
\text { in our school for effective curriculum implementation. }\end{array}$ & 4.26 & 1.329 & Very High \\
\hline & Grand Mean & \multicolumn{3}{|l|}{4.01} \\
\hline
\end{tabular}

Source: Computed from field data (2019).

The results from the above table means that there is very high level of effectiveness of manpower plan implementation and there exist significant influence of manpower plan implementation on staff retention in Senior Secondary Schools in Adamawa State. This finding is in line with the findings of Muhibat, Ayoni, Oladimeji, and Tramiyu (2016) which state that there exists a positive relationship between training/staff development and financial performance of respondents. Also, the finding is in line with the findings of Ozioma, and Ekwe (2014) which state that there is a positive relationship between training/development and organizational effectiveness. 
Level of Effectiveness of Manpower Plan Evaluation in Senior Secondary schools in Adamawa State

Table 2 reveals the mean and standard deviation of the level of effectiveness of manpower plan evaluation in Senior Secondary Schools in Adamawa State. It was shown that a calculated mean score of 4.26 with a standard deviation of 1.330 was obtained for item 1 , which states that teachers are posted to school early. The decision for item 1 was considered very high. A mean score of 4.09 with a standard deviation of 1.370 was obtained for item 2 , which states that qualified teachers are usually recruited before a new session begins. The decision for item 2 is regarded as very high. A mean score of 3.90 with a standard deviation of 1.435 was obtained for item 3 , which states that remuneration of staff is quite encouraging and is regularly reviewed. The decision for item 3 is regarded as moderately high. A mean score of 3.84 with a standard deviation of 1.436 was obtained for item 4 , which states that conflicts among staff usually linger before solution are sought. The decision for item 4 is regarded as moderately high. A mean score of 4.16 with a standard deviation of 1.360 was achieved for item 5 , which states that there is case of delay in promotion of staff. The decision for item 5 is regarded as very high.

Table 2 Mean and Standard Deviation of the level of effectiveness of manpower plan evaluation in Senior Secondary Schools in Adamawa State

\begin{tabular}{|c|c|c|c|c|}
\hline $\mathrm{S} / \mathrm{N}$ & Item & Mean & $\begin{array}{l}\text { Std. } \\
\text { Dev. }\end{array}$ & Decision \\
\hline 1. & Teachers are posted to school early. & 4.26 & 1.330 & Very High \\
\hline 2. & $\begin{array}{l}\text { Qualified teachers are usually recruited before a new } \\
\text { session begins. }\end{array}$ & 4.09 & 1.370 & Very High \\
\hline 3. & $\begin{array}{l}\text { Remuneration of staff is quite encouraging and is } \\
\text { regularly reviewed. }\end{array}$ & 3.90 & 1.435 & $\begin{array}{l}\text { Moderately } \\
\text { High }\end{array}$ \\
\hline 4. & $\begin{array}{l}\text { Conflicts among staff usually liger before solution are } \\
\text { sought. }\end{array}$ & 3.84 & 1.436 & $\begin{array}{l}\text { Moderately } \\
\text { High }\end{array}$ \\
\hline 5. & There is case of delay in promotion of staff. & 4.16 & 1.360 & Very High \\
\hline 6. & $\begin{array}{l}\text { There is regular supervision and evaluation of staff for } \\
\text { quality output. }\end{array}$ & 4.22 & 1.348 & Very High \\
\hline 7. & $\begin{array}{l}\text { Approval is granted to staff recommended for training } \\
\text { and development. }\end{array}$ & 4.16 & 1.368 & Very High \\
\hline 8. & $\begin{array}{l}\text { There are instances where P.T.A employ and pay staff } \\
\text { rather than the government of the state. }\end{array}$ & 3.83 & 1.424 & $\begin{array}{l}\text { Moderately } \\
\text { High }\end{array}$ \\
\hline 9. & $\begin{array}{l}\text { Though induction and orientation programmes are } \\
\text { good, there is hardly enough time to do so each time } \\
\text { new staff are posted to the school. }\end{array}$ & 3.91 & 1.372 & $\begin{array}{l}\text { Moderately } \\
\text { High }\end{array}$ \\
\hline
\end{tabular}




\begin{tabular}{|l|l|l|l|l|}
\hline 10. & $\begin{array}{l}\text { Principals are supervised to ensure that subordinate } \\
\text { staff are fairly treated. }\end{array}$ & 4.22 & 1.345 & Very High \\
\hline & Grand Mean & 4.06 & \\
\hline
\end{tabular}

Source: Computed from field data (2019).

The results obtained above means that there is very high level of effectiveness of manpower plan evaluation and there exist significant influence of manpower plan evaluation on staff retention in Senior Secondary Schools in Adamawa State. This is in line with the study of Amboka and Fred (2014) which revealed that there exists a relationship between strategic human resource planning and employee retention.

\section{Conclusion and Recommendation}

Concluding from the findings of this study, it was deduced that the nature of manpower plan implementation and manpower plan evaluation determines staff retention. The fact established in this study has brought about the conclusion that manpower plan implementation and evaluation significantly influenced staff retention in senior secondary schools in Adamawa State. It can be concluded that:

There exists significant influence of manpower plan implementation effectiveness on staff retention in Senior Secondary Schools in Adamawa State.

There exists significant influence of manpower plan evaluation effectiveness on staff retention in Senior Secondary Schools in Adamawa State.

Based on the conclusions reached, the study suggests the following. These recommendations if implemented will go a long way in solving those fundamental problems identified in this study.

The government should come out with a comprehensive, clearly articulated and documented Manpower Training and Development policy. The staff development should be made to function effectively. All staff should be given a copy of this Training and Development Policy document.

The various Study Leaves as we have in the schools are different from real Staff Training and Development Program. This is to an extend can only meet the academic and professional needs of the staff, especially the academic staff. Although, through study leave staff could be trained and developed, but real training and development program are initiated by organization based on identified individual needs and the needs of the organization. Therefore, Training and Development Programme should be initiated based on some identified needs of the staff and the schools as a whole.

Consequently, more of off-the-job training programme should be initiated. This could help in meeting up with some training needs that could arise as a result of technology change, school expansion, educational reforms, national manpower needs, etc.

Staff training and development should not be a privilege, the management of the schools should see it as a right of every staff and they should note be restricted from enjoying it.

The school management should ensure that staff training is regular and continuous and should not be sporadic. Training should not be seen as one of the routine activities of the school. 
The school management should as much as possible identify areas of needs of the staff. This is a very important aspect of staff training policy. If this is not done, any training programme undertaken will be a waste of time and resource.

\section{References}

Amboka, A. A., \& Fred, S. (2014). The influence of human resource management practices on employees retention in Kenya Power Company Ltd. Global Journal of Commerce \& Management Perspective, 3(4), 74-78.

Asfaw, A. Argaw, M., \& Bayissa, J. (2015). The impact of training and development on employee performance and effectiveness. A case study of district 5 administration office, Bole Sub-City, Addis Ababa, Ethiopia. Journal of Human Resource and Sustainability Studies, 3, 188-202.

Budur, T., \& Demir, A. (2019a). Leadership effects on employee perception about CSR in Kurdistan Region of Iraq. International Journal of Social Sciences \& Educational Studies, 6(1). 142-154.

Budur, T., \& Demir, A. (2019b). Leadership perceptions based on gender, experience, and education. International Journal of Social Sciences \& Educational Studies, 6(1), 142-154.

Budur, T., \& Poturak, M. (2021). Employee Performance and Customer Loyalty: Mediation effect of Customer Satisfaction. Middle East Journal of Management.

Budur, T., \& Poturak, M. (2021). Transformational leadership and its impact on customer satisfaction. Measuring mediating effects of organisational citizenship behaviours. Middle East Journal of Management, 8(1), 67-91.

Chukwuka, E. J. (2016). Effect of human resource management practices on employee performance in Nigerian public service. Lambert Academic Publishers.

Demir, A., Budur, T., \& Heshmati, A. (2020). Antecedents of trust, corporate image, and switching costs: a case in telecommunication services in the Kurdistan region of Iraq. International Journal of Mobile Communications, 19(1), 5374.

Demir, A., Budur, T., Hiwa, M., \& Heshmati, A. (2021). Links between Knowledge Management and Organizational Sustainability: Does the ISO 9001 certification have an effect? Knowledge Management Research \& Practice (TKMR), Doi: $10.1080 / 14778238.2020 .1860663$

Ezeani, N.E., \& Oladele, R. (2013). Implications of training and development programmes on accountants productivity in selected business organizations in Onitsha, Anambra State, Nigeria. International Journal of Asian Social Science, 3(1), 266-281.

Mohammed, K. S., Rashid, C. A., Salih, H. A., \& Budur, T. (2020). The Role of Online Teaching Tools on the Perception of the Students during the Lockdown of Covid-19. International Journal of Social Sciences \& Educational Studies, 7(3), 178190.

Mohammed, S. S., Suleyman, C., \& Taylan, B. (2020). Burnout Determinants and Consequences Among University Lecturers. Amazonia Investiga, 9(27), 13-24.

Muhibat, I. Ayoni, M. J., Oladimeji, J., \& Tiamiyu, L. O. (2016). The empirical evaluation of effect of training and staff development on organizational performance of Islamic financial institutions in Nigeria. Business and Management Research Journal, 6 (10), 109 - 117.

Nassari, A. (2013). Effects of training on employee performance: Evidence from Uganda. Unpublished M.Sc. Thesis, Vaasan Ammattikorkeakoulu University of Applied Sciences, Uganda.

Ofoegbu, R. U., \& Ofoegbu, W. C. (2017). Influence of staff management of academic productivity in senior schools in Port Harcourt Local Government area of River State. International Journal of Advanced Academic Research, Social Management Sciences, 3(9), 96-109

Okoye, P. V. C., \& Ezejiofor, R. A. (2013). The effect of human resources development on organization productivity. International Journal of Academic Research in Business and Social Sciences, 3(10), 250-268.

Ozioma H. O., \& Ekwe, M. C. (2014). Impact of $t \backslash$ Training and development on organizational effectiveness. European Journal of Business and Management, 6(29), 2014 
Peter, A. (2014). The effect of human capital development on employee commitment in the judicial service: A case study of Western Region. Ghana.

Poturak, M., Mekić, E., Hadžiahmetović, N., \& Budur, T. (2020). Effectiveness of Transformational Leadership among Different Cultures. International Journal of Social Sciences \& Educational Studies, 7(3), 119-129.

Scribd (2013). Human resources management training and development (Online). Retrieved from http://www.scribd.com/doc/10041934/HRM-Training-Development.

Torlak, N. G., Demir, A., \& Budur, T. (2019). Impact of operations management strategies on customer satisfaction and behavioral intentions at café-restaurants. International Journal of Productivity and Performance Management. Vol. 69 No. 9, pp. 1903-1924.

Torlak, N. G., Demir, A., \& Budur, T. (2021). Decision-making, leadership and performance links in private education institutes. Rajagiri Management Journal. Doi:10.1108/RAMJ-10-2020-0061.

Torlak, N. G., Kuzey, C., Dinc, MS., \& Budur, T. (2021). Links connecting nurses' planned behavior, burnout, job satisfaction and organizational citizenship behavior. Journal of Workplace Behavioral Health. Doi:10.1080/15555240.2020.1862675

Wisker, Z. L., \& Kwiatek, P. (2019). Environmental orientation and employee-based brand equity in 4 to 5 star hotels. Anatolia, 1-16. DOI:10.1080/13032917.2019.1604393

Zaim, H., Demir, A., \& Budur, T. (2020). Ethical leadership, effectiveness and team performance: An Islamic perspective. Middle East Journal of Management, 8(1), 42-66. 